\title{
Cytotoxicity of synthetic derivatives against breast cancer and multi-drug resistant breast cancer cell lines: a literature-based perspective study
}

\author{
Shabnam Sharmin ${ }^{1}$, Md. Mizanur Rahaman ${ }^{1}$, Miquel Martorell ${ }^{2}$, Jorge Sastre-Serra ${ }^{3,4,5}$, Javad Sharifi-Rad ${ }^{6^{*}}$, \\ Monica Butnariu ${ }^{7 *}$, Iulia Cristina Bagiu ${ }^{8,9}$, Radu Vasile Bagiu ${ }^{8,10}$ and Mohammad Torequl Islam ${ }^{1}$
}

\begin{abstract}
Cancer is the second most killer worldwide causing millions of people to lose their lives every year. In the case of women, breast cancer takes away the highest proportion of mortality rate than other cancers. Due to the mutation and resistance-building capacity of different breast cancer cell lines against conventional therapies, this death rate is on the verge of growth. New effective therapeutic compounds and treatment method is the best way to look out for in this critical time. For instance, new synthetic derivatives/ analogues synthesized from different compounds can be a ray of hope. Numerous synthetic compounds have been seen enhancing the apoptosis and autophagic pathway that directly exerts cytotoxicity towards different breast cancer cell lines. To cease the ever-growing resistance of multidrug resistant cells against anti-breast cancer drugs (Doxorubicin, verapamil, tamoxifen) synthetic compounds may play a vital role by increasing effectivity, showing synergistic action. Many recent and previous studies have reported that synthetic derivatives hold potentials as an effective anti-breast cancer agent as they show great cytotoxicity towards cancer cells, thus can be used even vastly in the future in the field of breast cancer treatment. This review aims to identify the anti-breast cancer properties of several synthetic derivatives against different breast cancer and multi-drug-resistant breast cancer cell lines with their reported mechanism of action and effectivity.
\end{abstract}

Keywords: Synthetic derivatives, Breast cancer cell line, MDR breast cancer cell line, Cytotoxicity

\section{Introduction}

Cancer is typically a heterogeneous disease and one of the second dominant causes of morbidity and mortality around the globe $[1,2]$. This disease revolves around unnatural cell proliferation which may or may not invade the other parts of the body. Among all the cancer types, breast cancer is most deadly for women and also

\footnotetext{
*Correspondence: javad.sharifirad@gmail.com; monicabutnariu@yahoo.com

${ }^{6}$ Phytochemistry Research Center, Shahid Beheshti University of Medical Sciences, Tehran, Iran

${ }^{7}$ Banat's University of Agricultural Sciences and Veterinary Medicine "King Michael I of Romania" From Timisoara, Timisoara, Romania

Full list of author information is available at the end of the article
}

contributes to the highest mortality rate when compared to other types [3-7]. According to World Health Organization (WHO) breast cancer is very persistent in women, affecting about 2.3 million each year. In 2020, approximately 685,000 women died from this disease [8]. Estrogen receptor beta (ER $\beta$ ) has been marked as a possible origin of developing breast cancer and around $60 \%$ of breast cancer is hormone-dependent, relying on estrogen for growth $[3,9,10]$. Abnormality and irregularity in the normal cell cycle along with obstructed apoptosis signaling pathway is the fundamental cause for breast cancer progression [11-13]. A subtype of breast cancer investigated as triple-negative breast cancer (TNBC) is a result original author(s) and the source, provide a link to the Creative Commons licence, and indicate if changes were made. The images or other third party material in this article are included in the article's Creative Commons licence, unless indicated otherwise in a credit line to the material. If material is not included in the article's Creative Commons licence and your intended use is not permitted by statutory regulation or exceeds the permitted use, you will need to obtain permission directly from the copyright holder. To view a copy of this licence, visit http://creativecommons.org/licenses/by/4.0/. The Creative Commons Public Domain Dedication waiver (http://creativeco mmons.org/publicdomain/zero/1.0/) applies to the data made available in this article, unless otherwise stated in a credit line to the data. 
of a shortfall of expression of estrogen receptor alpha/ progesterone receptor $[9,14,15]$.

As for the treatment's concern, radiation therapy, chemotherapy, hormone therapy, and targeted therapy are often used alongside surgery for early-stage patients [16-18]. Patients with metastatic disease are also treated the same way with systemic therapy which recently included immunotherapy [18]. Most of these therapies incorporate apoptosis or programmed cell death to instigate the anti-breast cancer activity throughout development, differentiation, tumor cell detection, and in response to specific cytotoxicity of molecules or compounds [19-22]. This programmed cell death follows an intrinsic or extrinsic pathway that comes with a series of occurrences including the altered ratio of $\mathrm{Bax} / \mathrm{Bcl}-2$ protein, activated caspases, and bifurcated poly [ADP-ribose] polymerase (PARP-1) enzyme [21, 23-27]. Generation of reactive oxygen species (ROS) and formation of nitric oxide (NO) also leads to p53 activation which results in DNA damage of cancer cells [28-31]. Autophagy, a cellular homeostasis mechanism may also contribute to breast cancer cell death where autophagosomes amalgamate with the lysosome to establish autophagolysosome during starvation and stress [32]. PARP-1 enlivening and LC3-II protein marker urges autophagic cell death [33, 34]. Figure 1 summarizes the mechanisms involved in breast cancer cell death.

Considering the complexity of the disease and the paucity of an effective chemotherapeutic agent, breast cancer besides other cancers has drawn the attention of researchers. Many of these researches have pointed towards chemotherapeutic agents that have been procured from natural or synthetic origin [21]. A slight modification in the structure of the natural compound or by the synthesis of specific analogues worthwhile activities is seen in the case of cancer therapy. Paclitaxel, vinca alkaloids, camtothecin, and etoposide are some of the synthetic derivatives vastly used for cancer therapy originally attained from natural sources [35]. Synthetically derived substances for cancer therapy are highly being studied in a hope that they might tame the unexpected and unavoidable side-effects originated by chemotherapeutic drugs [36]. A Wyrębska, K Gach, U Lewandowska, K Szewczyk, E Hrabec, J Modranka, R Jakubowski, T Janecki, J Szymański and A Janecka [37] reported the anti-breast cancer activity of synthetically derived $\alpha$-methylene$\delta$-lactones on hormone-independent MDA-MB-231, hormone-dependent MCF-7 cell lines through intrinsic apoptotic pathway activation, cancer cell migration suppression, and invasion. Synthetic vitamins, curcuminoids, isoflavones, chromenes are also seemed to have anti-breast cancer activity when tested on different cell lines [38-44].

Another vital road-blocker is the development of resistance that calls for never-ending neediness for new therapeutics [45-47]. Multi-drug resistance (MDR), the main fundamental cause behind chemotherapy failure may develop due to some complex mechanism including transporter-mediated efflux, over-expression of efflux transporters: P-glycoprotein (ABCB-1/P-gp),




breast cancer resistance protein (BCRP), and multidrug resistance-associated proteins (MRPs) present on the cell membrane [48-55]. Efflux transporters effectively pump out drugs that are meant to create cytotoxicity in the cell. As a result, the intracellular concentration of that specific drug fall. MDR cancer cells containing efflux or ATPbinding cassette $(A B C)$ transporters can significantly interact or deliver a plethora of anticancer compounds using the hydrophobic vacuum cleaner mode where the hydrophobic compounds get attach to the MDR-1 on account of their hydrophobicity for efflux [56]. In the case of a pump-independent mechanism, the cellular anti-apoptotic defense system activation develops resistance toward chemotherapeutic agents by upregulating BCL2 gene [57]. Evidence shows that synthetically derived compounds effectively exert cytotoxicity on MDR cancer cells. Zhou et al. [58], stated that synthetically derived $\beta$-amino ester inhibits P-gp activity by lowering mitochondrial membrane potentials and ATP levels on MCF-7 cell line. The enhanced antitumor effect might be attributed to PHP-mediated lysosomal escape and drug efflux inhibition.Various other studies show a similar effect on different tested cell lines.

Traditionally available chemotherapeutic agents may develop undesirable side effects and sometimes may also lack efficacy. So, new and advanced sources are in need that may counterbalance the present difficulties. In this study, the cytotoxic effect of different synthetic derivatives on normal and MDR cell lines is thoroughly discussed. This review set the sights on drawing the attention of researchers to conduct more advanced level analysis on the cytotoxicity of these synthetically derived analogues.

\section{Methodology}

A search (till February 2021) was done in the following databases: PubMed, Science Direct, MedLine, and Google Scholar with the keyword 'Synthetic derivative', paring with 'against breast cancer cell line/ multi-drugresistant breast cancer cell lines or cytotoxicity on breast cancer/ multidrug-resistant cell line. No language restrictions were imposed. Articles were assessed for information about the synthetic derivatives, breast cancer cell lines, multi-drug-resistant breast cancer cell lines, test results, and possible mechanisms of action.

\section{Inclusion criteria}

The following inclusion criteria were adopted:

1. Studies with synthetic derivatives/analogues from various sources.
2. Studies carried out in vivo, in vitro, or ex vivo on breast cancer cells/ multi-drug-resistant breast cancer cells.

3. Studies with or without activity mechanism.

\section{Exclusion criteria}

The following exclusion criteria were adopted:

1. Titles and/or abstract not meeting the inclusion criteria, duplication of data.

2. Synthetic derivatives with other studies obscuring the current subject of interest.

\section{Findings}

Among the vast pieces of evidence, some randomly selected published articles found in the databases that contain screening reports on synthetic derivatives acting against breast cancer/ MDR cell-line have been summarized below:

\section{Cytotoxicity of synthetic derivatives on different breast cancer cell lines}

Synthetic derivatives in a similar manner tonatural substances follow apoptosis and autophagic pathways to inhibit the growth and activity of breast cancer cells. Other than that inhibition of cell proliferation, induction of cell-cycle arrest may occur. AM Oliveira Rocha, F Severo Sabedra Sousa, V Mascarenhas Borba, SM T, J Guerin Leal, OE Dorneles Rodrigues, GF M, L Savegnago, T Collares and F Kömmling Seixas [59] reported the anti-breast cancer activity of synthetic azidothymidine (AZT) derivatives containing tellurium $(\mathrm{Te})$ on MDA-MB-231 cell-line using MTT assay. The derived compounds $7 \mathrm{~m}$ and $7 \mathrm{r}$ showed an inhibitory effect on the breast cancer cell-line through lowering cell proliferation, initiating cell-cycle arrest in the $\mathrm{S}$ phase in the absence of the apoptosis process. Subsequently, the synthetic drug pair, piperidinyl-diethylstilbestrol (DES), pyrrolidinyl-DES exhibits cytotoxicity on MCF-7 cell-line in both in vivo and in vitro assay. In the case of the in vitro study, these drugs manifest cytotoxicity on shrimp larvae at $\mathrm{LC}_{50} 19.7 \pm 0.95$ and $17.6 \pm 0.4 \mu \mathrm{g} / \mathrm{mL}$ respectively. In vivo cell inhibition is seen by ceasing G0/G1-phase of the MCF-7 cell cycle following $\mathrm{ED}_{50}$ value $7.9 \pm 0.38$ and $15.6 \pm 1.3 \mu \mathrm{g} / \mathrm{mL}$ [36].

The induction of apoptotic pathways can be an effective course of action to inhibit cancer cells. Studies reported a heap of incidences where apoptosis effectively took part in breast cancer cell destruction $[38,60,61]$. Kheirollahi et al. [39] reported the anti-breast activity of synthetic benzochromene derivatives on 3 different breast 


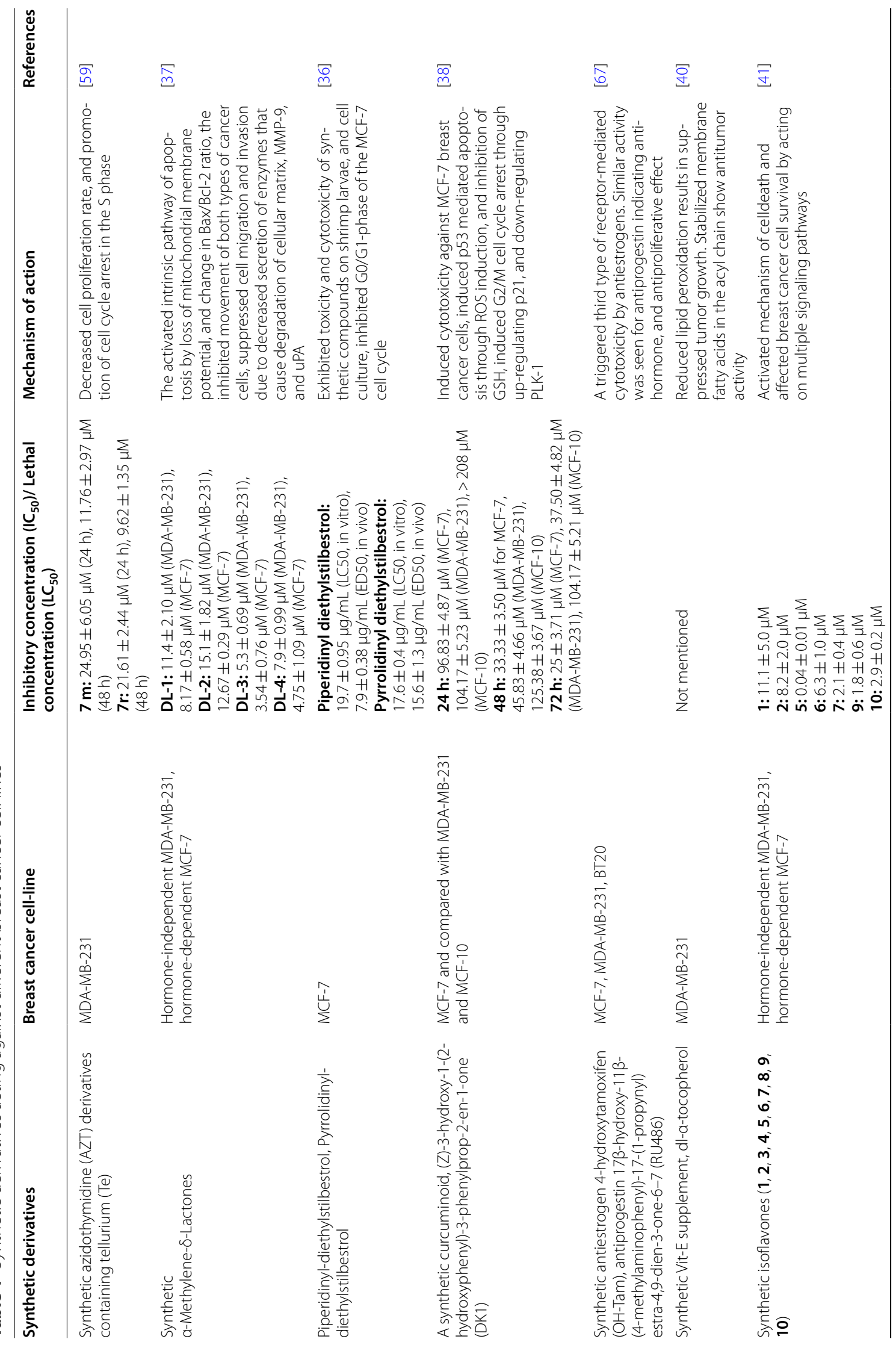




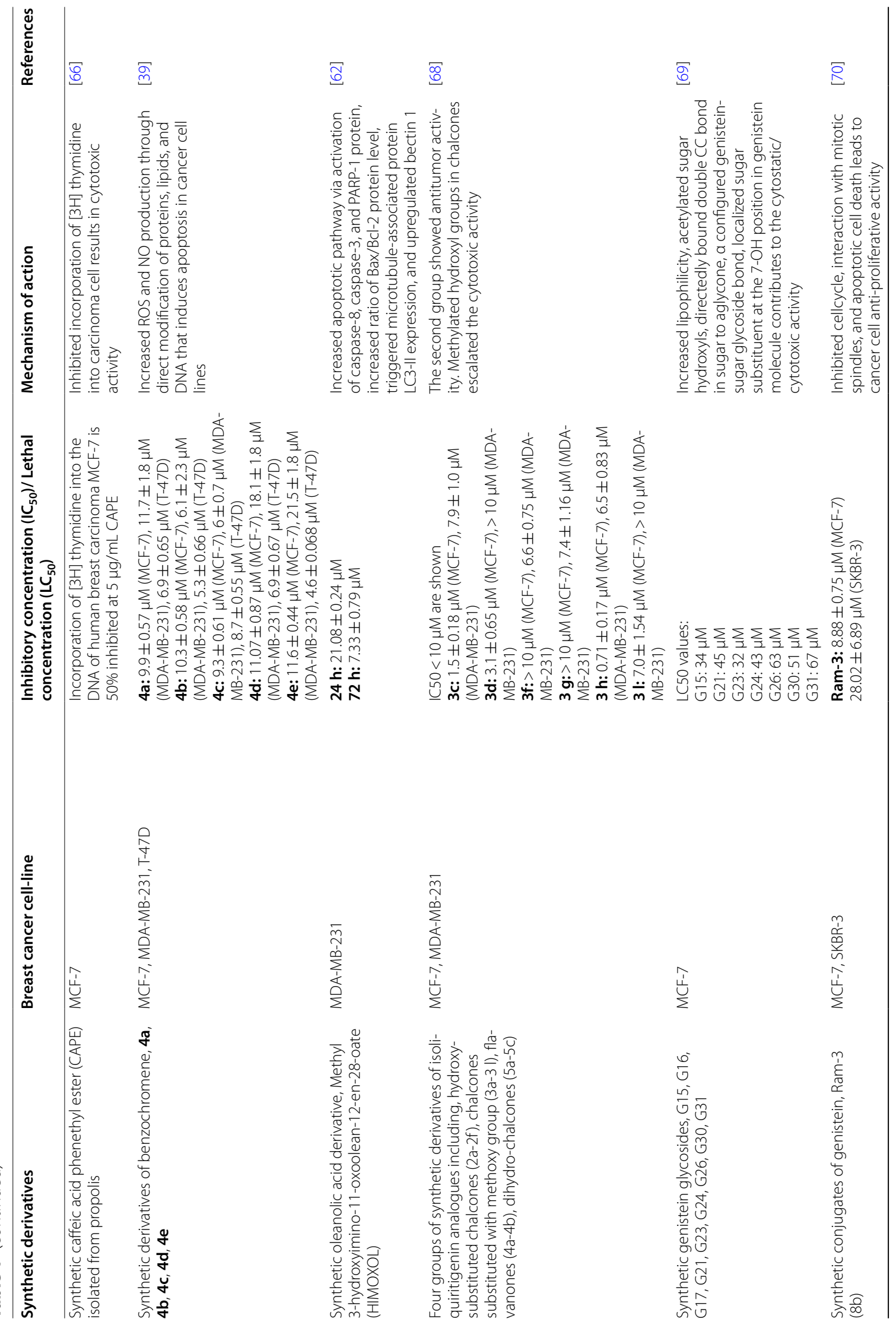




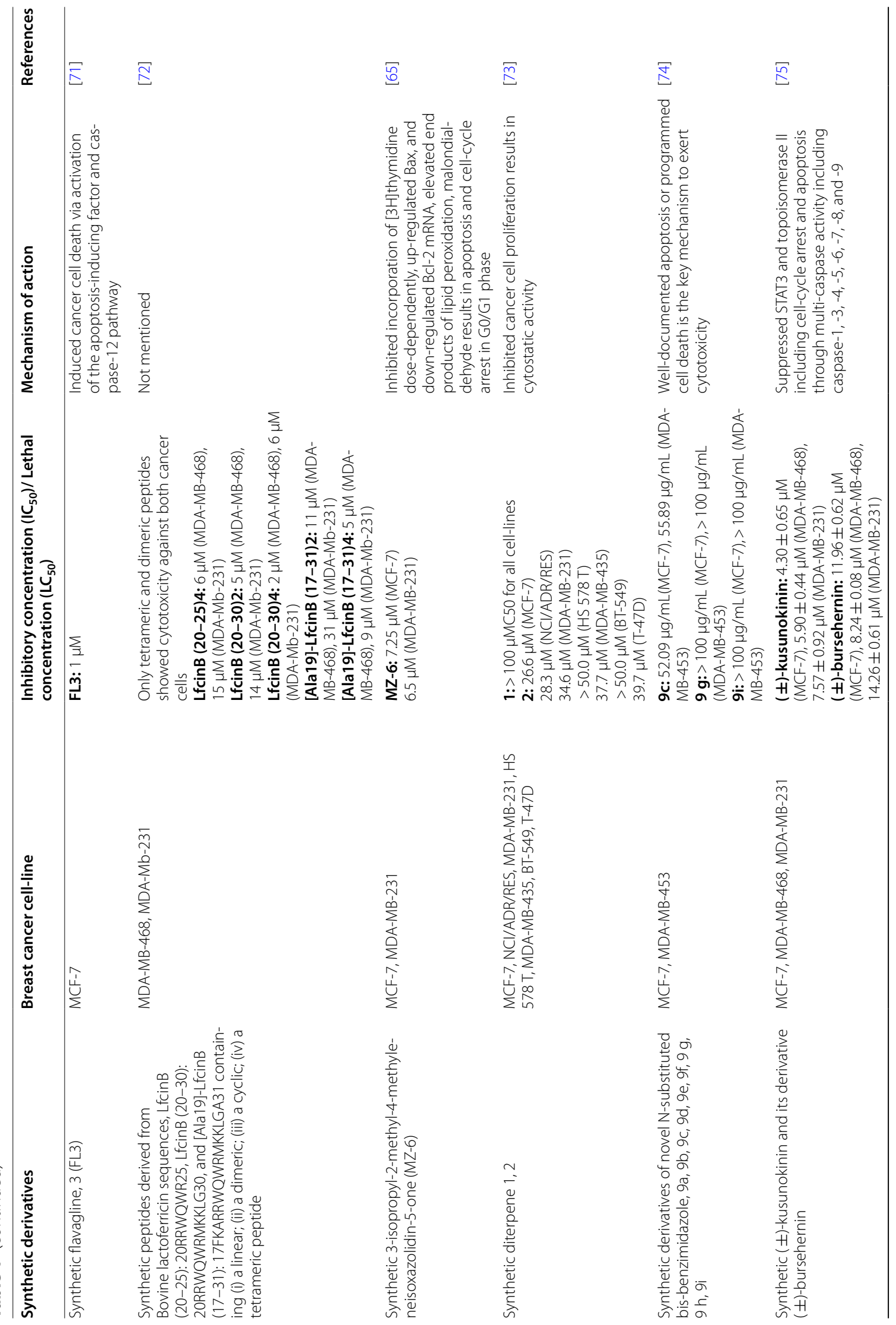




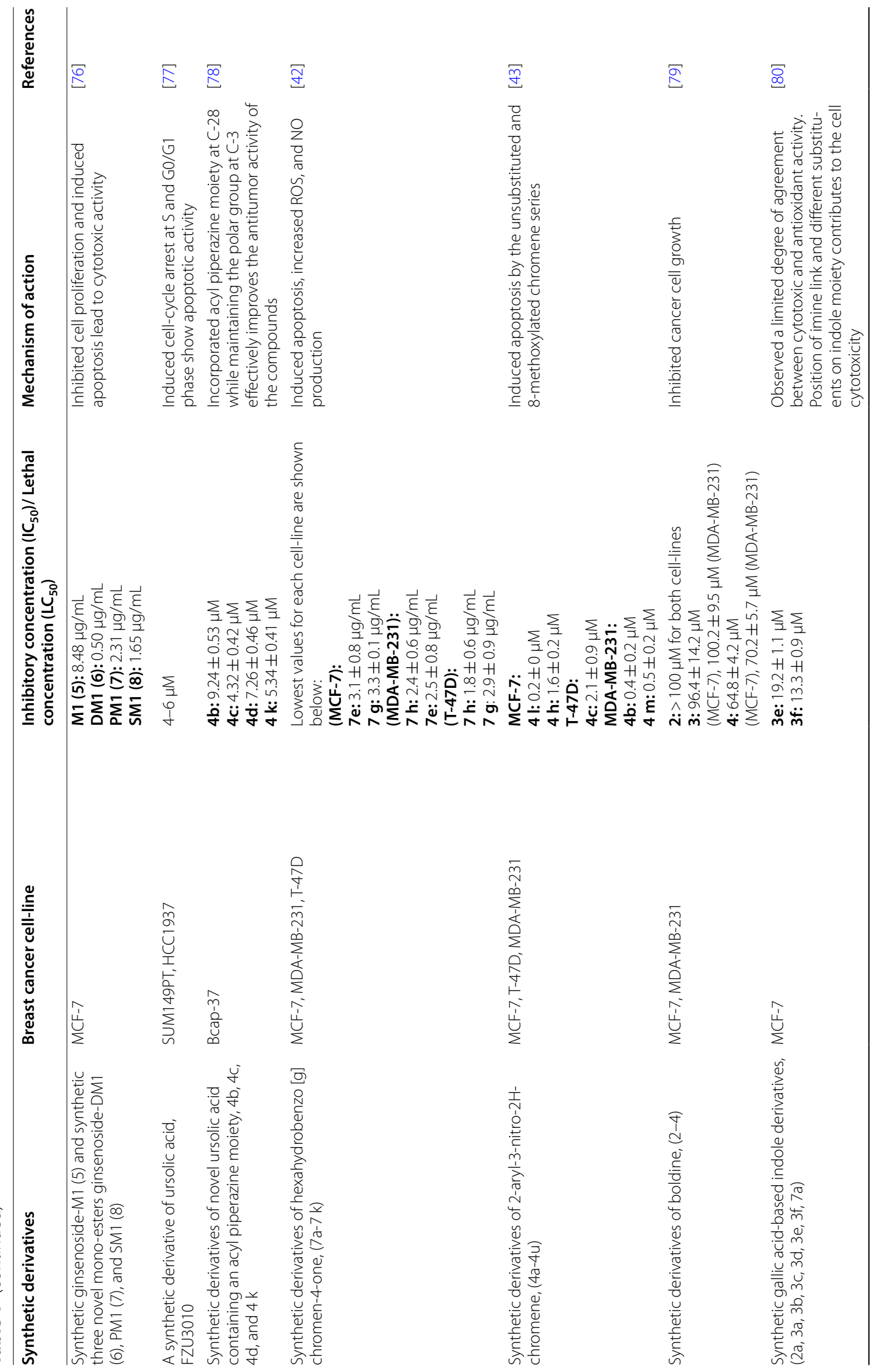




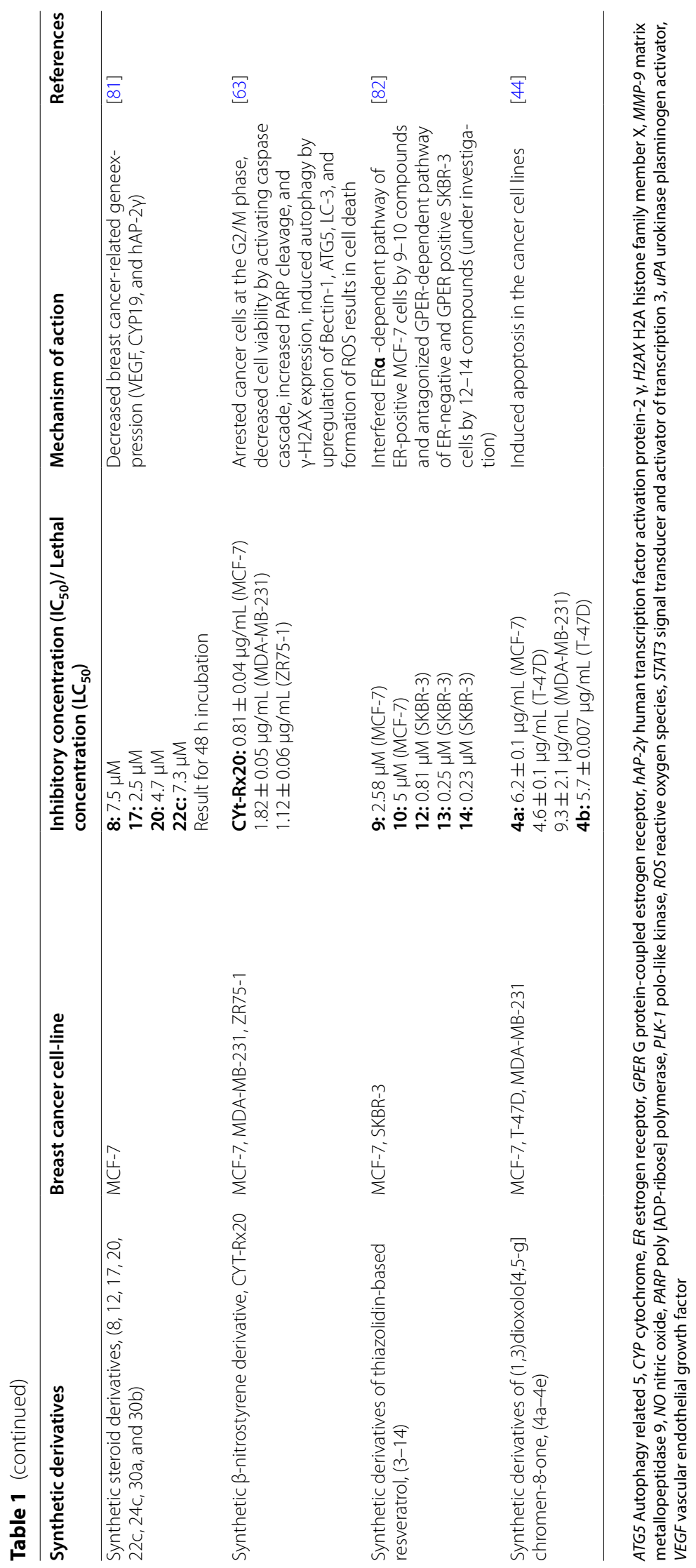


<smiles>C1=Cc2ccc3ccccc3c2OC1</smiles>

Benzochromene<smiles>COc1cc2c(cc1O)C[C@H]1c3c(cc(O)c(OC)c3-2)CCN1C</smiles>

Boldine<smiles>O=C(/C=C/c1ccc(O)c(O)c1)OCCc1ccccc1</smiles><smiles>O=C(CCc1ccccc1)c1ccccc1</smiles>

Caffeic acid phenethyl ester<smiles>O=C(O)c1cc(O)c(O)c(O)c1</smiles>

Gallic acid<smiles>c1ccc2[nH]ccc2c1</smiles>

Indole

Dihydrochalcones<smiles>O=c1c(-c2ccc(O)cc2)coc2cc(O)cc(O)c12</smiles>

Genistein

$\mathrm{HO}$<smiles>O=c1c(-c2ccc(O)cc2)coc2cc(I)ccc12</smiles>

Isoflavone<smiles>[R4]C#[W]</smiles><smiles>COc1ccc(C[C@H]2C(=O)OC[C@H]2Cc2ccc3c(c2)OCO3)cc1OC</smiles>

Bursehernin $\mathrm{HO}$<smiles>COc1cc(OC)c2c(c1)O[C@@]1(c3ccc(Br)cc3)[C@@H](c3ccccc3)C[C@@H](O)[C@@]21O</smiles>

Flavagline

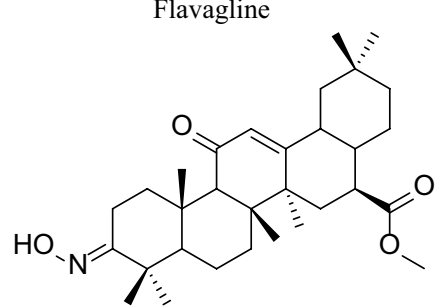

HIMOXOL

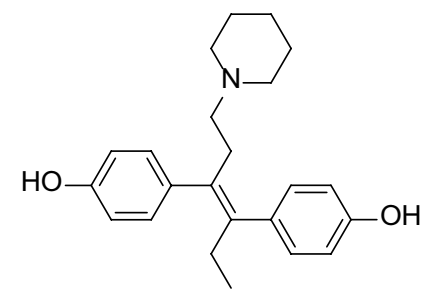

Piperidinyl-diethylstilbestrol

Fig. 2 Chemical structure of some synthetic derivatives that acting against different breast cancer cell lines

cancer cells (MCF-7, MDA-MB-231, and T-47D) where the derivatives participate in ROS and NO production through direct modification of proteins, lipids, and DNA that induces apoptosis in cancer cell lines. To that add this, synthetic oleanolic acid derivative HIMOXOL induced apoptotic pathway by activating caspase-8, caspase-3, and PARP-1 protein, elevating the ratio of Bax/ Bcl-2 protein level, triggering microtubule-associated protein LC3-II expression, and upregulating bectin 1 on MDA-MB-231 cell-line at $\mathrm{IC}_{50}$ value $7.33 \pm 0.79 \mu \mathrm{M}$ [62].

Autophagic pathway activation by synthetic derivatives is also marked as a potential solution in the case of cancer cell inhibition. Synthetic $\beta$-nitrostyrene derivative,
CYT-Rx20 shows inhibitory activity on MCF-7, MDAMB-231, and ZR75-1 cell-line with $\mathrm{IC}_{50}$ value $0.81 \pm 0.04$, $1.82 \pm 0.05$, and $1.12 \pm 0.06 \mu \mathrm{g} / \mathrm{mL}$ respectively. The cytotoxic mechanism behind this can be illustrated as arrested cancer cells at the G2/M phase, decreased cell viability by activating caspase cascade, increased PARP cleavage, and $\gamma-\mathrm{H} 2 \mathrm{AX}$ expression as well as induced autophagy by upregulation of Bectin-1, autophagy related 5 (ATG5), LC-3, and formation of ROS [63].

$[3 \mathrm{H}]$ Thymidine is often incorporated into the daughter strands of DNA during the mitotic cell division process. As $[3 \mathrm{H}]$ thymidine may directly calculate the proliferation so inhibition of incorporation often points 


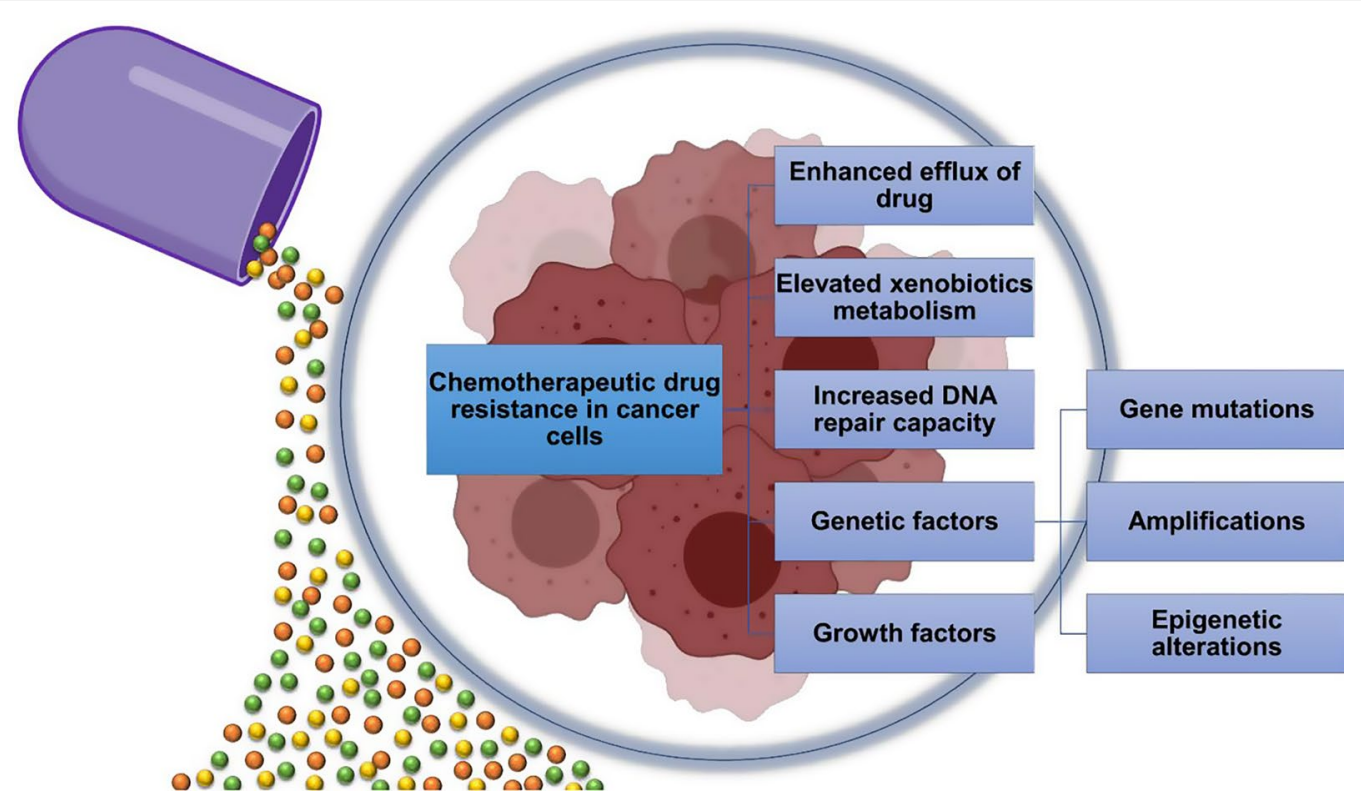

Fig. 3 Mechanisms of chemotherapeutic drug resistance in cancer cells

towards anti-proliferative activity [64]. Synthetic derivatives effectively inhibit $[3 \mathrm{H}]$ thymidine incorporation into the breast cancer cell to promote activity. Wyrębska et al. [65] stated that synthetic derivative MZ-6 inhibited incorporation of $[3 \mathrm{H}]$ thymidine dose-dependently alongside induced apoptosis into MCF-7, MDA-MB-231 breast cancer cell line. Furthermore, Synthetic caffeic acid phenethyl ester (CAPE) isolated from propolis shows a similar result when tested upon MCF-7 at $\mathrm{IC}_{50}$ $5 \mu \mathrm{g} / \mathrm{mL}[66]$.

Table 1 summarizes the synthetic derivatives acting against different breast cancer cell lines and Fig. 2 represents the chemical structures of these compounds.

\section{Cytotoxicity of synthetic derivatives on different multi-drug resistant (MDR) cancer cell lines}

Resistance against drugs used for a specific purpose can be a hugely troublesome matter when it comes to the treatment of a serious disease like cancer. Not only in the case of treatment but also in the case of the development of new therapeutics, "Multi-drug resistance" can be an invisible obstacle in pharmacology [83]. The resistance of tumor cells towards chemotherapeutic agents, leading to the failure of cancer treatment can be defined as MDR $[45,46]$. MDR of cancer cells during chemotherapy should be associated with a different type of mechanisms that are including enhanced efflux of drugs, genetic factors (gene mutations, amplifications, and epigenetic alterations), growth factors, increased DNA repair capacity, and also elevated metabolism of xenobiotics (Fig. 3). In the case of breast cancer, advancements in treatment and prevention have taken place over the last decade but MDR has been witnessed as the main roadblock [48]. In recent years, the use of different synthetically derived substances has been seen effective against MDR breast cancer cells.

One of the major reasons for MDR is the over-expression of P-gp, a protein encoded by the MDR-1 gene belonging to the $\mathrm{ABC}$ membrane transporters family. HB Xu, L Li and GQ Liu [84] reported that a synthetic derivative Guggulsterone shows an MDR-reversal effect, a valuable adjunct to chemotherapy. Increased intracellular accumulation of Doxorubicin, an antibreast cancer drug, results in the expression Guggulsterone in both MRP1 and P-gp in drug-resistant MCF-7 cells. Again sphingosine stereoisomers, another synthetic compound reduces basal phosphorylation of the $\mathrm{P}$-gp ion in MCF-7/ADR cells, suggesting inhibition of protein kinase $\mathrm{C}$ (PKC)-mediated phosphorylation of P-gp [85]. 1,4-Dihydropyridines (DHPs) 3-pyridyl methyl carboxylate and alkyl carboxylate moieties inhibited rhodamine 123 efflux showing the mechanism of MDR reversal in P-gp transporter modulation. Lowered resistance of MES-SA/DX5 to doxorubicin also exerted the anti-tumor effect in MCF-7ADR cells [86].

Additionally, induction of apoptosis and autophagy can be effective ways to look out for. Genistein at $\mathrm{IC}_{50}$ value $73.89 \mu \mathrm{M}$ showed an anti-tumor effect against MCF-7 cells. Induced cell-cycle arrest and apoptosis caused by genistein treatment strongly inhibits HER2/ 


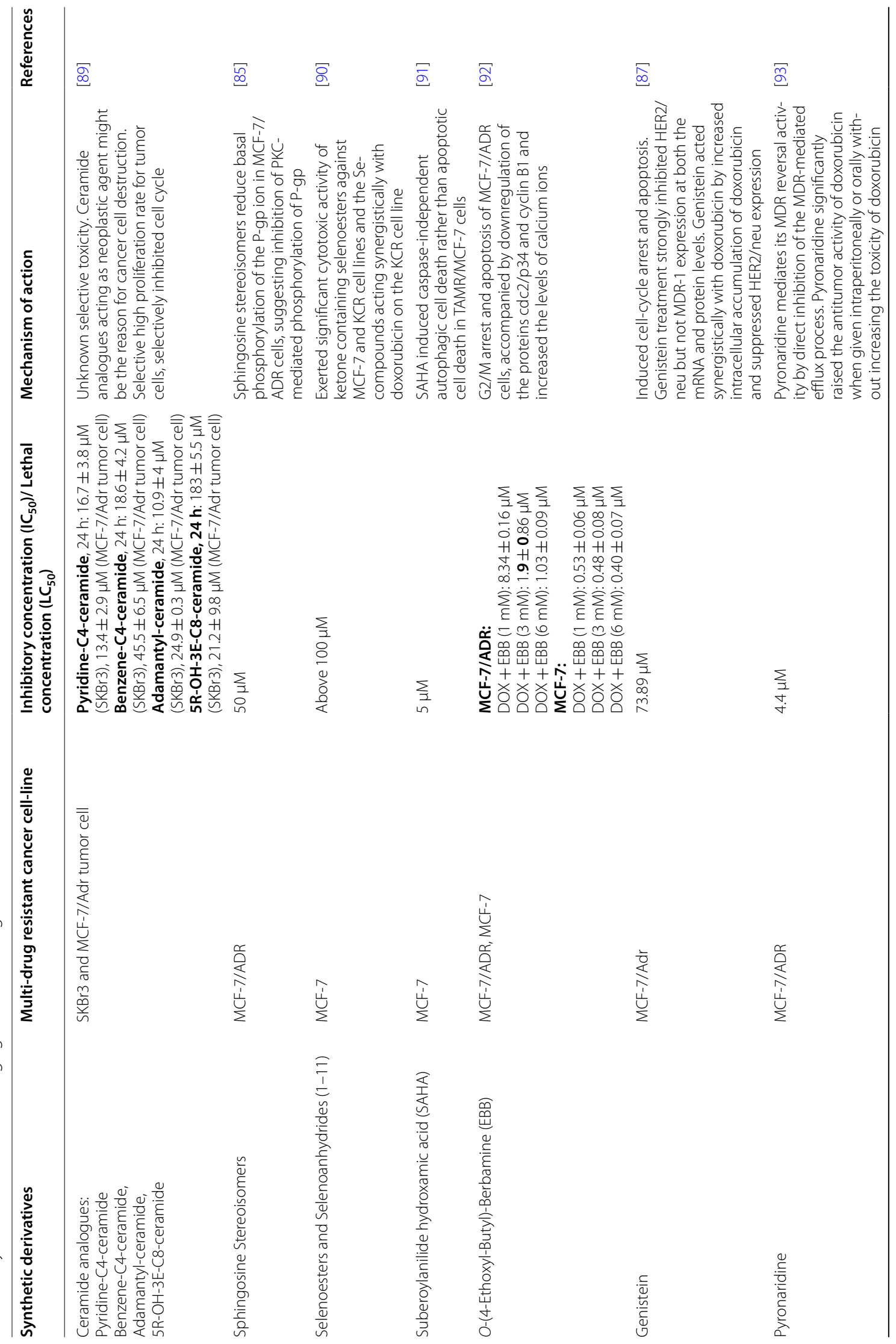




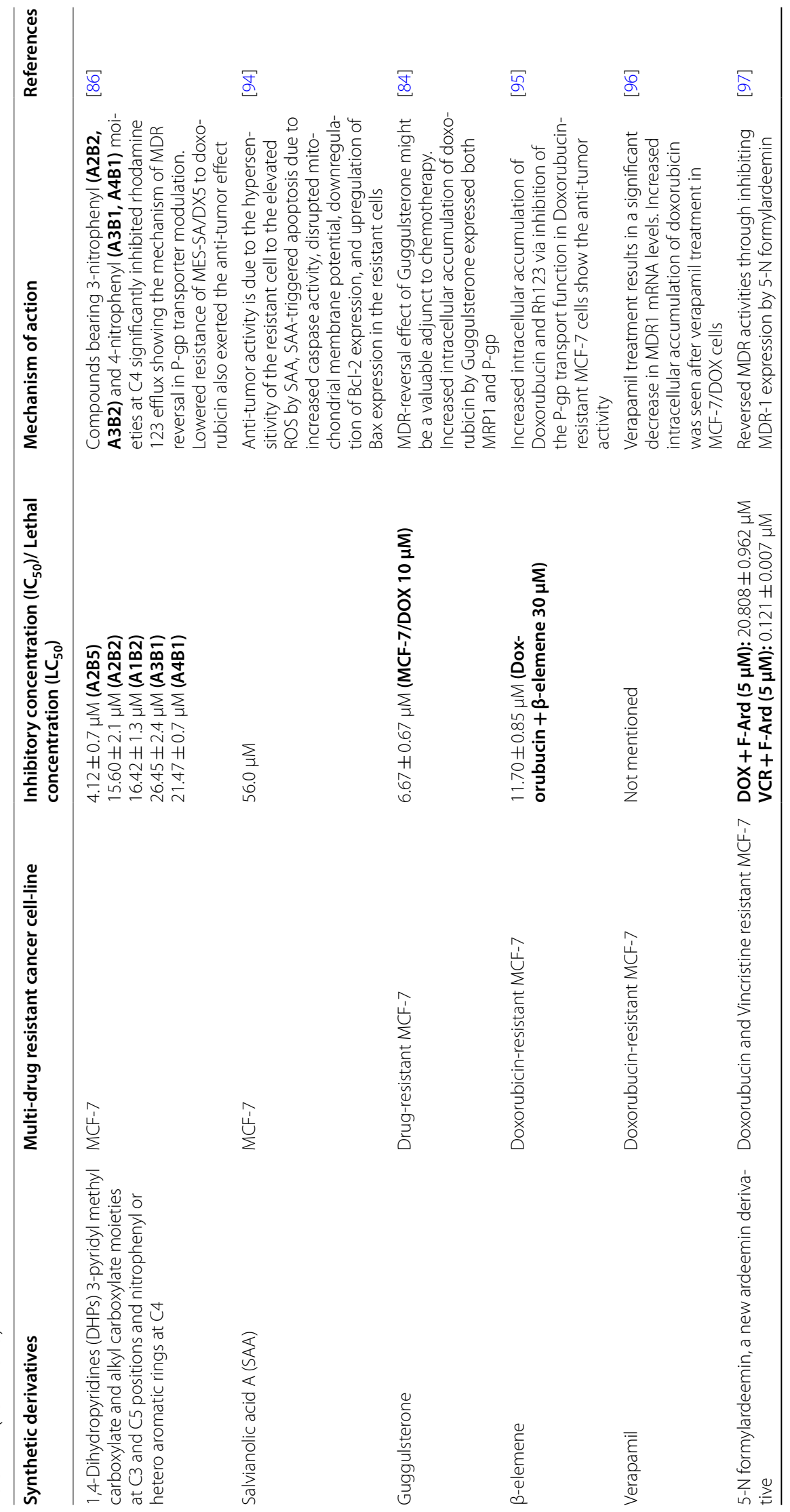




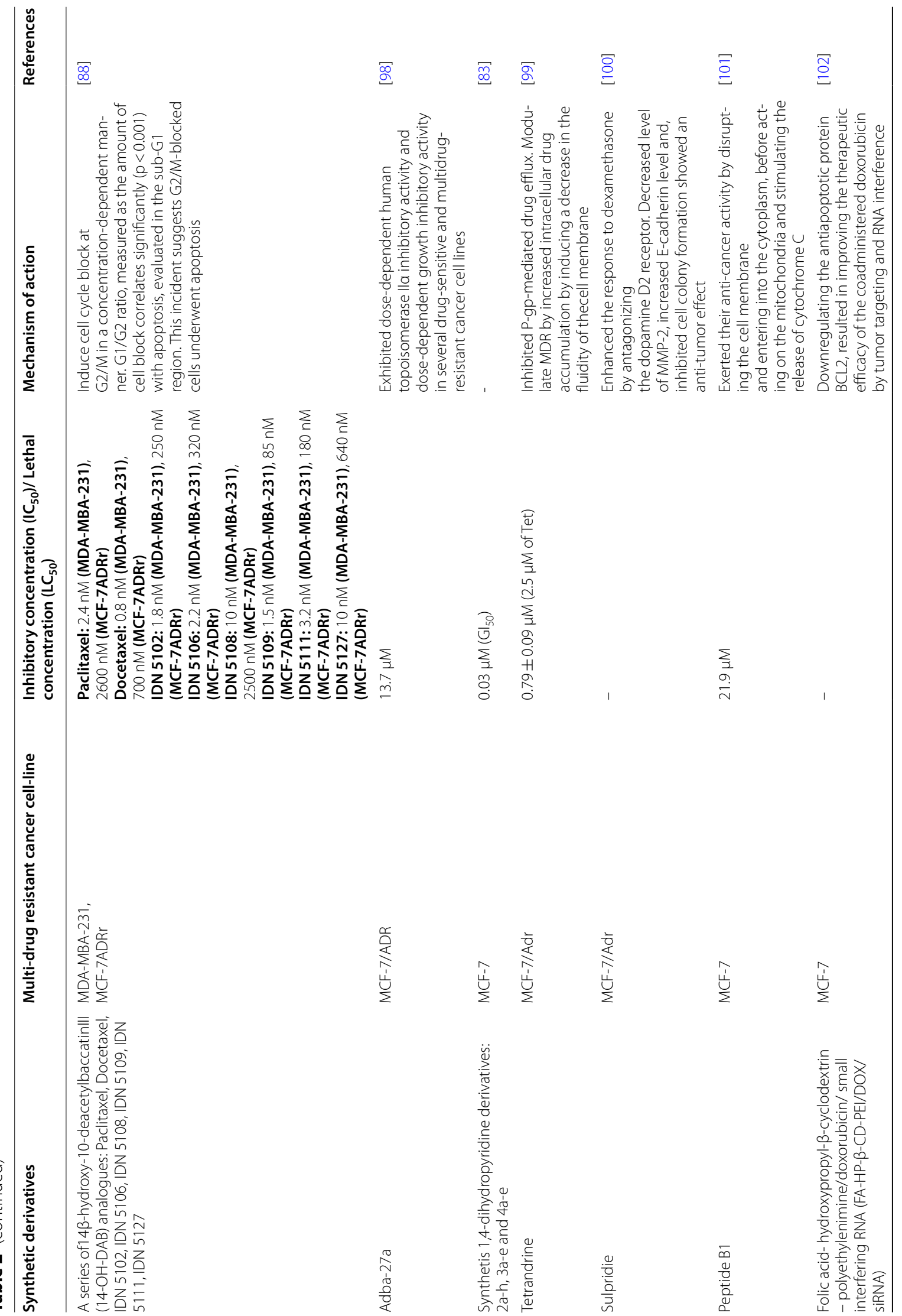




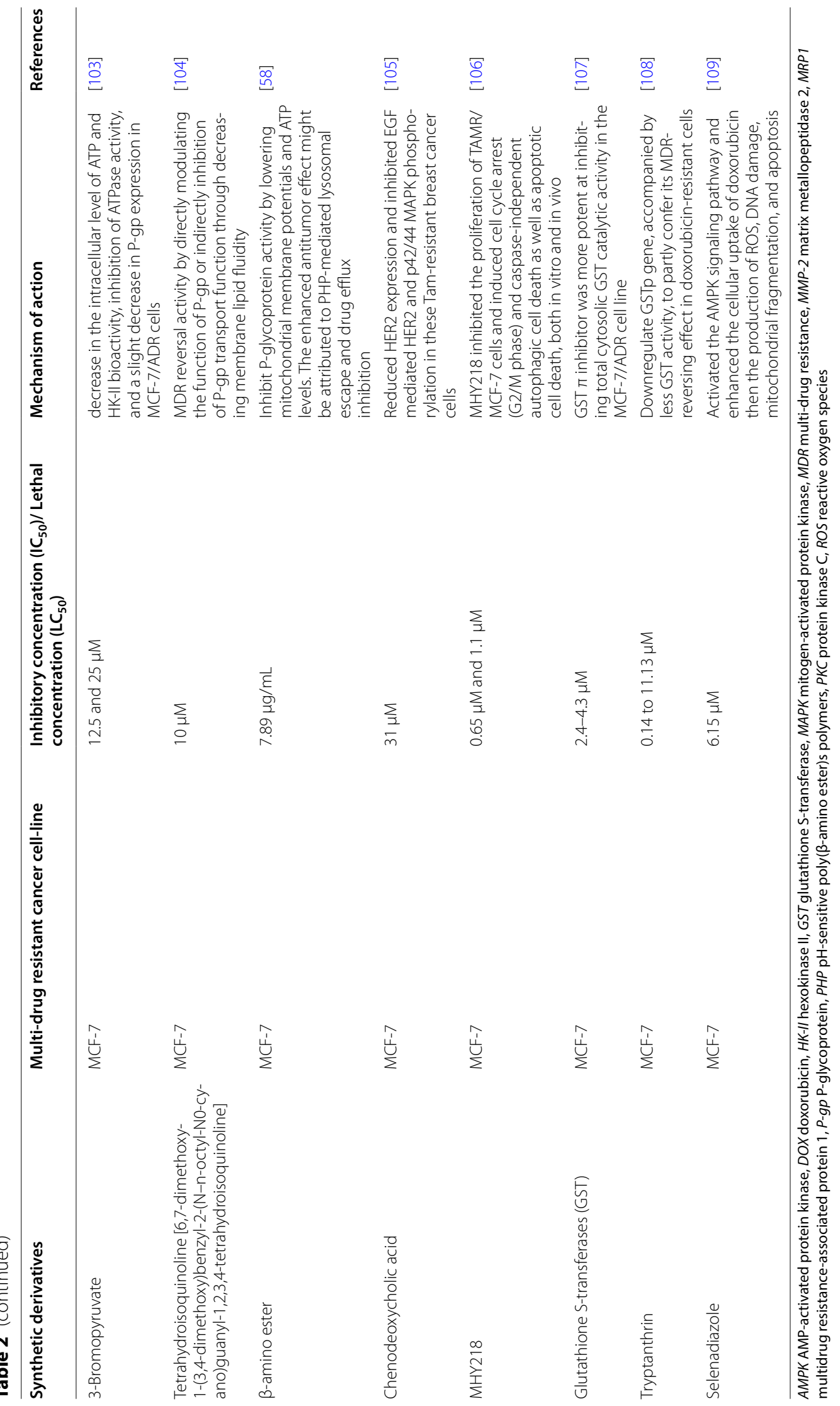


<smiles>O=C(O)C(=O)CBr</smiles><smiles>C=CC1(C)CCC(C(=C)C)CC1C(=C)C</smiles>

3-Bromopyruvate<smiles>Cc1nc(N)nc2ncc(CNc3ccc(C(=O)N[C@@H](CCC(=O)O)C(=O)O)cc3)nc12</smiles>

Folic acid<smiles>CC(CCC(=O)O)[C@H]1CC[C@H]2[C@H]3[C@H](CC[C@@]21C)[C@@]1(C)CC[C@H](O)C[C@@H]1C[C@H]3O</smiles>

Chenodeoxycholic acid
$\mathrm{HO}$<smiles>Cc1cc(O)c2c(=O)c(-c3ccc(O)cc3)coc2c1</smiles>

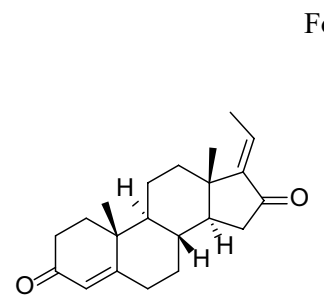

Guggulsterone

$$
\text { N-Se }
$$

Selenadiazole<smiles>O=C(CCCCCCC(=O)Nc1ccccc1)NO</smiles>

Suberoylanilide hydroxamic acid<smiles></smiles>

Tetrandrine<smiles>COc1ccc2nc3cc(Cl)ccc3c(Nc3cc(CN4CCCC4)c(O)c(CN4CCCC4)c3)c2n1</smiles>

Pyronaridine<smiles>O=C(/C=C/c1ccc(O)c(O)c1/C=C/c1ccc(O)c(O)c1)O[C@@H](Cc1ccc(O)c(O)c1)C(=O)O</smiles>

Salvianolic acid A<smiles>CCCCCCCCCCCCC/C=C/[C@@H](O)C(N)CO</smiles>

Sphingosine<smiles>CCN1CCC(CNC(=O)c2cc(S(N)(=O)=O)ccc2OC)C1</smiles>

Sulpridie<smiles>c1ccc2c(c1)CCNC2</smiles>

Tetrahydroisoquinoline<smiles>O=C1c2ccccc2-n2c1nc1ccccc1c2=O</smiles><smiles>COc1ccc(CCN(C)CCCC(C#N)(c2ccc(OC)c(OC)c2)C(C)C)cc1OC</smiles>

Tryptanthrin

Verapamil

Fig. 4 Chemical structure of some synthetic derivatives that acting against multi-drug resistant MCF-7 cell-line

neu but not MDR-1 expression at both the mRNA and protein levels. Geinstein acts synergistically with doxorubicin by increasing intracellular accumulation of doxorubicin and suppressed HER2/neu expression [87]. M Distefano, G Scambia, C Ferlini, C Gaggini, R De Vincenzo, A Riva, E Bombardelli, I Ojima, A Fattorossi,
PB Panici, et al. [88] stated that a series of $14 \beta$-hydroxy10-deacetylbaccatin III (14-OH-DAB) analogues induce cell cycle block at $\mathrm{G} 2 / \mathrm{M}$ in a concentration-dependent manner. G1/G2 ratio, measured as the amount of cell block correlates significantly $(\mathrm{p}<0.001)$ with apoptosis, evaluated in the sub-G1 region. This incident suggests 
G2/M-blocked cells underwent apoptosis in both MDA-MBA-231, MCF-7ADRr cells.

Table 2 summarizes the synthetic derivatives acting against multi-drugresistant MCF-7 cell-line and Fig. 4 represents the chemical structures of these compounds.

\section{Conclusion}

The most common type of cancer is breast cancer for women worldwide, and approximately $25 \%$ of all female malignancies that have a high appearance in most of the developed countries. The second leading cause of death due to cancer among females in the world is breast cancer. The mortality rate of breast cancer is higher than the other types of cancer. Recent studies give evidence that the synthetic derivatives give effective action against breast cancer cell lines and also give action against multi drug resistant in MCF-7 cell lines. This review offers a very large amount of data on the mechanism of action of synthetic derivatives on multidrug resistance and could provide the basis for the discovery of new drugs against breast cancer. Multi drug resistance of cancer cells during chemotherapy it has been associated with a different type of mechanisms that are including enhanced efflux of drugs, genetic factors (gene mutations, amplifications, and epigenetic alterations), growth factors, increased DNA repair capacity, and also elevated metabolism of xenobiotics. For this reason, further studies required for the future purpose to know more about synthetic derivatives activity against breast cancer and multi drug resistance breast cancer cell lines.

\section{Acknowledgements}

These are to the Department of Pharmacy, Bangabandhu Sheikh Mujibur Rahman Science and Technology Univerity, Gopalganj (8100), Dhaka, Bangladesh.

\section{Authors' contributions}

The work was supervised by MM, MB, JS-R, MTI. Project administration was performed by JS-R, MB, and MTIm. Final draft of the work was by SS, ICB, RVB, Md.MR, MM, JS-S, JS-R and MTI. All authors read and approved the final manuscript.

\section{Funding}

No Funding received but Will Pay the APC.

\section{Availability of data and materials}

Not applicable.

\section{Declarations}

Ethics approval and consent to participate

Not applicable.

\section{Consent for publication}

Not applicable.

\section{Competing interests}

The authors declare that they have no competing interests.

\section{Author details}

${ }^{1}$ Department of Pharmacy, Life Science Faculty, Bangabandhu Sheikh Mujibur Rahman Science and Technology University, Gopalganj (Dhaka) 8100, Bangladesh. ${ }^{2}$ Department of Nutrition and Dietetics, Faculty of Pharmacy, and Centre for Healthy Living, University of Concepción, 4070386 Concepción, Chile. ${ }^{3}$ Grupo Multidisciplinar de Oncología Traslacional, Institut Universitari d'Investigació en Ciències de La Salut (IUNICS), Universitat de Les Illes Balears, Palma de Mallorca, Illes Balears, Spain. ${ }^{4}$ Instituto de Investigación Sanitaria de Las Islas Baleares (IdISBa), Hospital Universitario Son Espases, Edificio S, 07120 Palma de Mallorca, Illes Balears, Spain. ${ }^{5}$ Ciber Fisiopatología Obesidad y Nutrición (CB06/03), Instituto Salud Carlos III, 28029 Madrid, Spain. ${ }^{6}$ Phytochemistry Research Center, Shahid Beheshti University of Medical Sciences, Tehran, Iran. ${ }^{7}$ Banat's University of Agricultural Sciences and Veterinary Medicine "King Michael I of Romania" From Timisoara, Timisoara, Romania. ${ }^{8}$ Department of Microbiology, Victor Babes University of Medicine and Pharmacy of Timisoara, Timisoara, Romania. ${ }^{9}$ Multidisciplinary Research Center On Antimicrobial Resistance, Timisoara, Romania. ${ }^{10}$ Preventive Medicine Study Center, Timisoara, Romania.

Received: 29 June 2021 Accepted: 31 October 2021

Published online: 20 November 2021

\section{References}

1. McGuire S: World Cancer Report 2014. Geneva, Switzerland: World Health Organization, International Agency for Research on Cancer, WHO Press, 2015. Adv Nutr 2016, 7(2):418-419.

2. Jemal A, Bray F, Center MM, Ferlay J, Ward E, Forman D. Global cancer statistics. CA Cancer J Clin. 2011;61(2):69-90.

3. Siegel R, Ward E, Brawley O, Jemal A. Cancer statistics, 2011: the impact of eliminating socioeconomic and racial disparities on premature cancer deaths. CA Cancer J Clin. 2011;61(4):212-36.

4. Siegel R, Ma J, Zou Z, Jemal A. Cancer statistics, 2014. CA Cancer J Clin. 2014:64(1):9-29.

5. Satsangi A, Roy SS, Satsangi RK, Tolcher AW, Vadlamudi RK, Goins B, Ong JL. Synthesis of a novel, sequentially active-targeted drug delivery nanoplatform for breast cancer therapy. Biomaterials. 2015:59:88-101.

6. Lin KL, Tsai PC, Hsieh CY, Chang LS, Lin SR. Antimetastatic effect and mechanism of ovatodiolide in MDA-MB-231 human breast cancer cells. Chem Biol Interact. 2011;194(2-3):148-58.

7. Keshtgar M, Davidson T, Pigott K, Falzon M, Jones A. Current status and advances in management of early breast cancer. Int J Surg. 2010;8(3):199-202.

8. WHO: Breast cancer. World Health Organization (WHO) Report 2021, 26 March 2021.

9. Yu XL, Jing T, Zhao H, Li PJ, Xu WH, Shang FF. Curcumin inhibits expression of inhibitor of DNA binding 1 in PC3 cells and xenografts. Asian Pac J Cancer Prev. 2014;15(3):1465-70.

10. Parsai S, Keck R, Skrzypczak-Jankun E, Jankun J. Analysis of the anticancer activity of curcuminoids, thiotryptophan and 4-phenoxyphenol derivatives. Oncol Lett. 2014;7(1):17-22.

11. Liu H, Liu YZ, Zhang F, Wang HS, Zhang G, Zhou BH, Zuo YL, Cai SH, Bu $X Z$, Du J. Identification of potential pathways involved in the induction of cell cycle arrest and apoptosis by a new 4-arylidene curcumin analogue T63 in lung cancer cells: a comparative proteomic analysis. Mol Biosyst. 2014;10(6):1320-31.

12. Solary E, Dubrez L, Eymin B. The role of apoptosis in the pathogenesis and treatment of diseases. Eur Respir J. 1996;9(6):1293-305.

13. Favaloro B, Allocati N, Graziano V, Di llio C, De Laurenzi V. Role of apoptosis in disease. Aging (Albany NY). 2012;4(5):330-49.

14. Bourgeois-Daigneault MC, St-Germain LE, Roy DG, Pelin A, Aitken AS, Arulanandam R, Falls T, Garcia V, Diallo JS, Bell JC. Combination of Paclitaxel and MG1 oncolytic virus as a successful strategy for breast cancer treatment. Breast Cancer Res. 2016;18(1):83.

15. Kreike $B$, van Kouwenhove $M$, Horlings $H$, Weigelt $B$, Peterse $H$, Bartelink $\mathrm{H}$, van de Vijver MJ. Gene expression profiling and histopathological characterization of triple-negative/basal-like breast carcinomas. Breast Cancer Res. 2007:9(5):R65. 
16. Richie RC, Swanson JO. Breast cancer: a review of the literature. J Insur Med. 2003;35(2):85-101.

17. Satija A, Ahmed SM, Gupta R, Ahmed A, Rana SP, Singh SP, Mishra S, Bhatnagar S. Breast cancer pain management - a review of current \& novel therapies. Indian J Med Res. 2014;139(2):216-25.

18. Street W. Breast Cancer Facts \& Figures 2019-2020. Am Cancer Soc. 2019;1:1-38.

19. Huang P, Robertson LE, Wright S, Plunkett W. High molecular weight DNA fragmentation: a critical event in nucleoside analogue-induced apoptosis in leukemia cells. Clin Cancer Res. 1995;1(9):1005-13.

20. Safavi M, Esmati N, Ardestani SK, Emami S, Ajdari S, Davoodi J, Shafiee A, Foroumadi A. Halogenated flavanones as potential apoptosis-inducing agents: synthesis and biological activity evaluation. Eur J Med Chem. 2012;58:573-80

21. LuY, Mahato RI. Pharmaceutical perspectives of cancer therapeutics. New York: Springer Science \& Business Media; 2009

22. Xie K, Huang S. Contribution of nitric oxide-mediated apoptosis to cancer metastasis inefficiency. Free Radic Biol Med. 2003;34(8):969-86.

23. D'Arcy MS. Cell death: a review of the major forms of apoptosis, necrosis and autophagy. Cell Biol Int. 2019:43(6):582-92.

24. Lowe SW, Lin AW. Apoptosis in cancer. Carcinogenesis. 2000;21(3):485-95.

25. Elmore S. Apoptosis: a review of programmed cell death. Toxicol Pathol. 2007;35(4):495-516.

26. Yang Z, Klionsky DJ. Mammalian autophagy: core molecular machinery and signaling regulation. Curr Opin Cell Biol. 2010;22(2):124-31.

27. Timmer JC, Salvesen GS. Caspase substrates. Cell Death Differ. 2007;14(1):66-72.

28. Kannan K, Jain SK. Oxidative stress and apoptosis. Pathophysiology. 2000;7(3):153-63.

29. Sinha K, Das J, Pal PB, Sil PC. Oxidative stress: the mitochondria-dependent and mitochondria-independent pathways of apoptosis. Arch Toxicol. 2013;87(7):1157-80.

30. Brown GC, Cooper CE. Nanomolar concentrations of nitric oxide reversibly inhibit synaptosomal respiration by competing with oxygen at cytochrome oxidase. FEBS Lett. 1994;356(2-3):295-8.

31. Sikora AG, Gelbard A, Davies MA, Sano D, Ekmekcioglu S, Kwon J, Hailemichael Y, Jayaraman P, Myers JN, Grimm EA, et al. Targeted inhibition of inducible nitric oxide synthase inhibits growth of human melanoma in vivo and synergizes with chemotherapy. Clin Cancer Res. 2010;16(6):1834-44

32. Fulda S, Gorman AM, Hori O, Samali A. Cellular stress responses: cell survival and cell death. Int J Cell Biol. 2010;2010:214074.

33. Mizushima N, Yoshimori T, Levine B. Methods in mammalian autophagy research. Cell. 2010;140(3):313-26.

34. Muñoz-Gámez JA, Rodríguez-Vargas JM, Quiles-Pérez R, Aguilar-Quesada R, Martín-Oliva D, de Murcia G. Menissier de Murcia J, Almendros A, Ruiz de Almodóvar M, Oliver FJ: PARP-1 is involved in autophagy induced by DNA damage. Autophagy. 2009;5(1):61-74.

35. Cragg GM, Newman DJ. Plants as a source of anti-cancer agents. J Ethnopharmacol. 2005;100(1-2):72-9.

36. Badisa RB, Darling-Reed SF, Joseph P, Cooperwood JS, Latinwo LM, Goodman CB. Selective cytotoxic activities of two novel synthetic drugs on human breast carcinoma MCF-7 cells. Anticancer Res. 2009;29(8):2993-6.

37. Wyrębska A, Gach K, Lewandowska U, Szewczyk K, Hrabec E, Modranka J, Jakubowski R, Janecki T, Szymański J, Janecka A. Anticancer Activity of New Synthetic a-Methylene- $\delta$-Lactones on Two Breast Cancer Cell Lines. Basic Clin Pharmacol Toxicol. 2013;113(6):391-400.

38. Ali NM, Yeap SK, Abu N, Lim KL, Ky H, Pauzi AZM, Ho WY, Tan SW, AlanOng HK, Zareen S, et al. Synthetic curcumin derivative DK1 possessed G2/M arrest and induced apoptosis through accumulation of intracellular ROS in MCF-7 breast cancer cells. Cancer Cell Int. 2017;17:30.

39. Kheirollahi A, Pordeli M, Safavi M, Mashkouri S, Naimi-Jamal MR, Ardestani SK. Cytotoxic and apoptotic effects of synthetic benzochromene derivatives on human cancer cell lines. Naunyn Schmiedebergs Arch Pharmacol. 2014;387(12):1199-208.

40. Cameron IL, Munoz J, Barnes CJ, Hardman WE. High dietary level of synthetic vitamin E on lipid peroxidation, membrane fatty acid composition and cytotoxicity in breast cancer xenograft and in mouse host tissue. Cancer Cell Int. 2003;3(1):3.

41. Davis DD, Díaz-Cruz ES, Landini S, Kim YW, Brueggemeier RW. Evaluation of synthetic isoflavones on cell proliferation, estrogen receptor binding affinity, and apoptosis in human breast cancer cells. J Steroid Biochem Mol Biol. 2008;108(1-2):23-31.

42. Pordeli M, Nakhjiri M, Safavi M, Ardestani SK, Foroumadi A. Anticancer effects of synthetic hexahydrobenzo [g]chromen-4-one derivatives on human breast cancer cell lines. Breast Cancer. 2017;24(2):299-311.

43. Rahmani-Nezhad S, Safavi M, Pordeli M, Ardestani SK, Khosravani L, Pourshojaei Y, Mahdavi M, Emami S, Foroumadi A, Shafiee A. Synthesis, in vitro cytotoxicity and apoptosis inducing study of 2-aryl-3-nitro-2Hchromene derivatives as potent anti-breast cancer agents. Eur J Med Chem. 2014;86:562-9.

44. Alipour E, Mousavi Z, Safaei Z, Pordeli M, Safavi M, Firoozpour L, Mohammadhosseini N, Saeedi M, Ardestani SK, Shafiee A, et al. Synthesis and cytotoxic evaluation of some new $[1,3]$ dioxolo[4,5-g]chromen-8one derivatives. Daru. 2014;22(1):41.

45. Gottesman MM. How cancer cells evade chemotherapy: sixteenth Richard and Hinda Rosenthal Foundation Award Lecture. Cancer Res. 1993;53(4):747-54.

46. Liscovitch M, Lavie Y. Cancer multidrug resistance: a review of recent drug discovery research. IDrugs. 2002;5(4):349-55.

47. Boer R, Gekeler V. Chemosensitizers in tumor therapy: new compounds promise better efficacy. Drugs of the Future. 1995;20(5):499-510.

48. Aller SG, Yu J, Ward A, Weng Y, Chittaboina S, Zhuo R, Harrell PM, Trinh YT, Zhang Q, Urbatsch IL, et al. Structure of P-glycoprotein reveals a molecular basis for poly-specific drug binding. Science. 2009:323(5922):1718-22.

49. Zahreddine H, Borden KL. Mechanisms and insights into drug resistance in cancer. Front Pharmacol. 2013:4:28.

50. Ling V. Multidrug resistance: molecular mechanisms and clinical relevance. Cancer Chemother Pharmacol. 1997;40(Suppl):S3-8.

51. Choudhuri S, Klaassen CD. Structure, function, expression, genomic organization, and single nucleotide polymorphisms of human $A B C B 1$ (MDR1), ABCC (MRP), and ABCG2 (BCRP) efflux transporters. Int J Toxicol. 2006;25(4):231-59.

52. Ozben T. Mechanisms and strategies to overcome multiple drug resistance in cancer. FEBS Lett. 2006;580(12):2903-9.

53. Palmeira A, Vasconcelos MH, Paiva A, Fernandes MX, Pinto M, Sousa E. Dual inhibitors of P-glycoprotein and tumor cell growth: (re)discovering thioxanthones. Biochem Pharmacol. 2012;83(1):57-68.

54. Lemos C, Jansen G, Peters GJ. Drug transporters: recent advances concerning BCRP and tyrosine kinase inhibitors. Br J Cancer. 2008;98(5):857-62.

55. Chen KG, Sikic BI. Molecular pathways: regulation and therapeutic implications of multidrug resistance. Clin Cancer Res. 2012;18(7):1863-9.

56. Higgins CF, Gottesman MM. Is the multidrug transporter a flippase? Trends Biochem Sci. 1992;17(1):18-21.

57. McCubrey JA, Steelman LS, Kempf CR, Chappell WH, Abrams SL, Stivala F, Malaponte G, Nicoletti F, Libra M, Bäsecke J, et al. Therapeutic resistance resulting from mutations in Raf/MEK/ERK and PI3K/PTEN/Akt/ mTOR signaling pathways. J Cell Physiol. 2011;226(11):2762-81.

58. Zhou M, Zhang X, Xie J, Qi R, Lu H, Leporatti S, Chen J, Hu Y. pH-Sensitive Poly( $\beta$-amino ester)s Nanocarriers Facilitate the Inhibition of Drug Resistance in Breast Cancer Cells. Nanomaterials (Basel). 2018;8:11.

59. Oliveira Rocha AM. Severo Sabedra Sousa F, Mascarenhas Borba V Guerin Leal J, Dorneles Rodrigues OE, M GF, Savegnago L, Collares T, Kömmling Seixas F: Evaluation of the effect of synthetic compounds derived from azidothymidine on MDA-MB-231 type breast cancer cells. Bioorg Med Chem Lett. 2020;30(17):127365.

60. Chen Y, Qin Y, Li L, Chen J, Zhang X, Xie Y. Morphine Can Inhibit the Growth of Breast Cancer MCF-7 Cells by Arresting the Cell Cycle and Inducing Apoptosis. Biol Pharm Bull. 2017;40(10):1686-92.

61. Stumm S, Meyer A, Lindner M, Bastert G, Wallwiener D, Gückel B. Paclitaxel treatment of breast cancer cell lines modulates Fas/Fas ligand expression and induces apoptosis which can be inhibited through the CD40 receptor. Oncology. 2004;66(2):101-11. 
62. Lisiak N, Paszel-Jaworska A, Bednarczyk-Cwynar B, Zaprutko L, Kaczmarek M, Rybczyńska M. Methyl 3-hydroxyimino-11-oxoolean-12-en28-oate (HIMOXOL), a synthetic oleanolic acid derivative, induces both apoptosis and autophagy in MDA-MB-231 breast cancer cells. Chem Biol Interact. 2014;208:47-57.

63. Hung AC, Tsai CH, Hou MF, Chang WL, Wang CH, Lee YC, Ko A, Hu SC, Chang FR, Hsieh PW, et al. The synthetic $\beta$-nitrostyrene derivative CYT-R×20 induces breast cancer cell death and autophagy via ROSmediated MEK/ERK pathway. Cancer Lett. 2016;371(2):251-61.

64. Hu VW, Black GE, Torres-Duarte A, Abramson FP. 3H-thymidine is a defective tool with which to measure rates of DNA synthesis. Faseb j. 2002;16(11):1456-7.

65. Wyrębska A, Szymański J, Gach K, Piekielna J, Koszuk J, Janecki T, Janecka A. Apoptosis-mediated cytotoxic effects of parthenolide and the new synthetic analog MZ-6 on two breast cancer cell lines. Mol Biol Rep. 2013:40(2):1655-63.

66. Grunberger D, Banerjee R, Eisinger K, Oltz EM, Efros L, Caldwell M, Este-

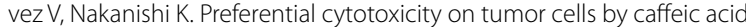
phenethyl ester isolated from propolis. Experientia. 1988;44(3):230-2.

67. Bardon S, Vignon F, Montcourrier P, Rochefort H. Steroid receptormediated cytotoxicity of an antiestrogen and an antiprogestin in breast cancer cells. Cancer Res. 1987;47(5):1441-8.

68. Peng F, Meng CW, Zhou QM, Chen JP, Xiong L. Cytotoxic Evaluation against Breast Cancer Cells of Isoliquiritigenin Analogues from Spatholobus suberectus and Their Synthetic Derivatives. J Nat Prod. 2016;79(1):248-51.

69. Polkowski K, Popiołkiewicz J, Krzeczyński P, Ramza J, Pucko W, ZegrockaStendel O, Boryski J, Skierski JS, Mazurek AP, Grynkiewicz G. Cytostatic and cytotoxic activity of synthetic genistein glycosides against human cancer cell lines. Cancer Lett. 2004;203(1):59-69.

70. Rusin A, Zawisza-Puchałka J, Kujawa K, Gogler-Pigłowska A, Wietrzyk J, Switalska M, Głowala-Kosińska M, Gruca A, Szeja W, Krawczyk Z, et al. Synthetic conjugates of genistein affecting proliferation and mitosis of cancer cells. Bioorg Med Chem. 2011;19(1):295-305.

71. Thuaud F, Bernard Y, Türkeri G, Dirr R, Aubert G, Cresteil T, Baguet A, Tomasetto C, Svitkin Y, Sonenberg N, et al. Synthetic analogue of rocaglaol displays a potent and selective cytotoxicity in cancer cells: involvement of apoptosis inducing factor and caspase-12. J Med Chem. 2009;52(16):5176-87.

72. Vargas Casanova Y, Rodríguez Guerra JA, Umaña Pérez YA, Leal Castro AL, Almanzar Reina G, García Castañeda JE, Rivera Monroy ZJ. Antibacterial Synthetic Peptides Derived from Bovine Lactoferricin Exhibit Cytotoxic Effect against MDA-MB-468 and MDA-MB-231 Breast Cancer Cell Lines. Molecules. 2017;22:10.

73. Alonso R, Gomis H, Taddei A, Sajo C. Cytostatic and Cytotoxic Activity of Synthetic Diterpene Derivatives Obtained from (-)-Kaur-9(11), 16-Dien19-Oic Acid Against Human Cancer Cell Lines. Lett Drug Des Discov. 2005:2(4):255-9.

74. Sukhramani PS, Sukhramani PS, Desai SA, Suthar MP. In-vitro cytotoxicity evaluation of novel $\mathrm{N}$-substituted bis-benzimidazole derivatives for anti-lung and anti-breast cancer activity. Ann Biol Res. 2011;2(1):51-9.

75. Rattanaburee T, Thongpanchang T, Wongma K, Tedasen A, Sukpondma $Y$, Graidist P. Anticancer activity of synthetic $( \pm)$-kusunokinin and its derivative $( \pm)$-bursehernin on human cancer cell lines. Biomed Pharmacother. 2019;117:109115

76. Lei J, Li X, Gong XJ, Zheng YN. Isolation, synthesis and structures of cytotoxic ginsenoside derivatives. Molecules. 2007;12(9):2140-50.

77. Li W, Zhang H, Nie M, Wang W, Liu Z, Chen C, Chen H, Liu R, Baloch Z, Ma K. A novel synthetic ursolic acid derivative inhibits growth and induces apoptosis in breast cancer cell lines. Oncol Lett. 2018;15(2):2323-9.

78. Liu MC, Yang SJ, Jin LH, Hu DY, Xue W, Song BA, Yang S. Synthesis and cytotoxicity of novel ursolic acid derivatives containing an acyl piperazine moiety. Eur J Med Chem. 2012;58:128-35.

79. Thomet FA, Pinyol P, Villena J, Espinoza LJ, Reveco PG. Cytotoxic thiocarbamate derivatives of boldine. Nat Prod Commun. 2010:5(10):1587-90.

80. Khaledi H, Alhadi AA, Yehye WA, Ali HM, Abdulla MA, Hassandarvish P. Antioxidant, cytotoxic activities, and structure-activity relationship of gallic acid-based indole derivatives. Arch Pharm (Weinheim). 2011;344(11):703-9.
81. Elmegeed GA, Khalil WK, Mohareb RM, Ahmed HH, Abd-Elhalim MM, Elsayed GH. Cytotoxicity and gene expression profiles of novel synthesized steroid derivatives as chemotherapeutic anti-breast cancer agents. Bioorg Med Chem. 2011;19(22):6860-72.

82. Sala M, Chimento A, Saturnino C, Gomez-Monterrey IM, Musella S, Bertamino A, Milite C, Sinicropi MS, Caruso A, Sirianni R, et al. Synthesis and cytotoxic activity evaluation of 2,3-thiazolidin-4-one derivatives on human breast cancer cell lines. Bioorg Med Chem Lett. 2013;23(17):4990-5.

83. Ahamed A, Arif IA, Mateen M, Surendra Kumar R, Idhayadhulla A. Antimicrobial, anticoagulant, and cytotoxic evaluation of multidrug resistance of new 1,4-dihydropyridine derivatives. Saudi J Biol Sci. 2018;25(6):1227-35.

84. Xu HB, Li L, Liu GQ. Reversal of multidrug resistance by guggulsterone in drug-resistant MCF-7 cell lines. Chemotherapy. 2011;57(1):62-70.

85. Sachs CW, Ballas LM, Mascarella SW, Safa AR, Lewin AH, Loomis C, Carroll Fl, Bell RM, Fine RL. Effects of sphingosine stereoisomers on P-glycoprotein phosphorylation and vinblastine accumulation in multidrug-resistant MCF-7 cells. Biochem Pharmacol. 1996;52(4):603-12.

86. Shekari F, Sadeghpour H, Javidnia K, Saso L, Nazari F, Firuzi O, Miri R. Cytotoxic and multidrug resistance reversal activities of novel 1,4-dihydropyridines against human cancer cells. Eur J Pharmacol. 2015;746:233-44

87. Xue JP, Wang G, Zhao ZB, Wang Q, Shi Y. Synergistic cytotoxic effect of genistein and doxorubicin on drug-resistant human breast cancer MCF-7/Adr cells. Oncol Rep. 2014;32(4):1647-53.

88. Distefano M, Scambia G, Ferlini C, Gaggini C, De Vincenzo R, Riva A, Bombardelli E, Ojima I, Fattorossi A, Panici PB, et al. Anti-proliferative activity of a new class of taxanes (14beta-hydroxy-10-deacetylbaccatin III derivatives) on multidrug-resistance-positive human cancer cells. Int J Cancer. 1997;72(5):844-50.

89. Crawford KW, Bittman R, Chun J, Byun HS, Bowen WD. Novel ceramide analogues display selective cytotoxicity in drug-resistant breast tumor cell lines compared to normal breast epithelial cells. Cell Mol Biol. 2003;49(7):1017-23.

90. Csonka A, Kincses A, Nové M, Vadas Z, Sanmartín C, Domínguez-Álvarez E, Spengler G. Selenoesters and selenoanhydrides as novel agents against resistant breast cancer. Anticancer Res. 2019;39(7):3777-83.

91. Lee YJ, Won AJ, Lee J, Jung JH, Yoon S, Lee BM, Kim HS. Molecular mechanism of SAHA on regulation of autophagic cell death in tamoxifenresistant MCF-7 breast cancer cells. Int J Med Sci. 2012;9(10):881-93.

92. Liu R, Zhang Y, Chen Y, Qi J, Ren S, Xushi MY, Yang C, Zhu H, Xiong D. A novel calmodulin antagonist O-(4-ethoxyl-butyl)-berbamine overcomes multidrug resistance in drug-resistant MCF-7/ADR breast carcinoma cells. J Pharm Sci. 2010;99(7):3266-75.

93. Qi J, Wang S, Liu G, Peng H, Wang J, Zhu Z, Yang C. Pyronaridine, a novel modulator of P-glycoprotein-mediated multidrug resistance in tumor cells in vitro and in vivo. Biochem Biophys Res Commun. 2004;319(4):1124-31.

94. Wang X, Wang C, Zhang L, Li Y, Wang S, Wang J, Yuan C, Niu J, Wang C, Lu G. Salvianolic acid A shows selective cytotoxicity against multidrug-resistant MCF-7 breast cancer cells. Anticancer Drugs. 2015:26(2):210-23.

95. Xu HB, Li L, Fu J, Mao XP, Xu LZ. Reversion of multidrug resistance in a chemoresistant human breast cancer cell line by $\beta$-elemene. Pharmacology. 2012;89(5-6):303-12.

96. Dönmez Y, Akhmetova L, İşeri ÖD, Kars MD, Gündüz U. Effect of MDR modulators verapamil and promethazine on gene expression levels of MDR1 and MRP1 in doxorubicin-resistant MCF-7 cells. Cancer Chemother Pharmacol. 2011;67(4):823-8.

97. Zheng X, Li D, Zhao C, Wang Q, Song H, Qin Y, Liao L, Zhang L, Lin $Y$, Wang $X$. Reversal of multidrug resistance in vitro and in vivo by 5 -N-formylardeemin, a new ardeemin derivative. Apoptosis. 2014:19(8):1293-300.

98. Merzouki A, Buschmann MD, Jean M, Young RS, Liao S, Gal S, Li Z, Slilaty SN. Adva-27a, a novel podophyllotoxin derivative found to be effective against multidrug resistant human cancer cells. Anticancer Res. 2012;32(10):4423-32.

99. Fu LW, Zhang YM, Liang YJ, Yang XP, Pan QC. The multidrug resistance of tumour cells was reversed by tetrandrine in vitro and in xenografts 
derived from human breast adenocarcinoma MCF-7/adr cells. Eur J Cancer. 2002;38(3):418-26.

100. Li J, Yao QY, Xue JS, Wang LJ, Yuan Y, Tian XY, Su H, Wang SY, Chen WJ, Lu W, et al. Dopamine D2 receptor antagonist sulpiride enhances dexamethasone responses in the treatment of drug-resistant and metastatic breast cancer. Acta Pharmacol Sin. 2017;38(9):1282-96.

101. Deng X, Qiu Q, Yang B, Wang X, Huang W, Qian H. Design, synthesis and biological evaluation of novel peptides with anti-cancer and drug resistance-reversing activities. Eur J Med Chem. 2015;89:540-8.

102. Li JM, Zhang W, Su H, Wang YY, Tan CP, Ji LN, Mao ZW. Reversal of multidrug resistance in MCF-7/Adr cells by codelivery of doxorubicin and BCL2 siRNA using a folic acid-conjugated polyethylenimine hydroxypropyl- $\beta$-cyclodextrin nanocarrier. Int J Nanomedicine. 2015;10:3147-62.

103. Wu L, Xu J, Yuan W, Wu B, Wang H, Liu G, Wang X, Du J, Cai S. The reversal effects of 3-bromopyruvate on multidrug resistance in vitro and in vivo derived from human breast MCF-7/ADR cells. PLOS ONE. 2014;9(11):e112132.

104. Li Y, Zhang HB, Huang WL, Li YM. Design and synthesis of tetrahydroisoquinoline derivatives as potential multidrug resistance reversal agents in cancer. Bioorg Med Chem Lett. 2008;18(12):3652-5.

105. Giordano C, Catalano S, Panza S, Vizza D, Barone I, Bonofiglio D, Gelsomino L, Rizza P, Fuqua SA, Andò S. Farnesoid X receptor inhibits tamoxifen-resistant MCF-7 breast cancer cell growth through downregulation of HER2 expression. Oncogene. 2011;30(39):4129-40.

106. Park JH, Ahn MY, Kim TH, Yoon S, Kang KW, Lee J, Moon HR, Jung JH, Chung HY, Kim HS. A new synthetic HDAC inhibitor, MHY218, induces apoptosis or autophagy-related cell death in tamoxifen-resistant MCF-7 breast cancer cells. Invest New Drugs. 2012;30(5):1887-98.

107. Wang K, Ramji S, Bhathena A, Lee C, Riddick DS. Glutathione S-transferases in wild-type and doxorubicin-resistant MCF-7 human breast cancer cell lines. Xenobiotica. 1999;29(2):155-70.

108. Yu ST, Chen TM, Chern JW, Tseng SY, Chen YH. Downregulation of GSTpi expression by tryptanthrin contributing to sensitization of doxorubicinresistant MCF-7 cells through c-jun NH2-terminal kinase-mediated apoptosis. Anticancer Drugs. 2009;20(5):382-8.

109. Zhao J, Zeng D, Liu Y, Luo Y, Ji S, Li X, Chen T. Selenadiazole derivatives antagonize hyperglycemia-induced drug resistance in breast cancer cells by activation of AMPK pathways. Metallomics. 2017;9(5):535-45.

\section{Publisher's Note}

Springer Nature remains neutral with regard to jurisdictional claims in published maps and institutional affiliations.
Ready to submit your research? Choose BMC and benefit from:

- fast, convenient online submission

- thorough peer review by experienced researchers in your field

- rapid publication on acceptance

- support for research data, including large and complex data types

- gold Open Access which fosters wider collaboration and increased citations

- maximum visibility for your research: over $100 \mathrm{M}$ website views per year

At BMC, research is always in progress.

Learn more biomedcentral.com/submissions 